\title{
SISTEM INFORMASI PENDAFTARAN ONLINE PENERIMA ZAKAT PADA BADAN AMIL ZAKAT NASIONAL (BAZNAS) KOTA PADANG
}

\author{
Sotar $^{1}$, Suci Amalia ${ }^{2}$ \\ Sistem Informasi, STMIK Indonesia Padang ${ }^{1,2}$ \\ sotar@stmikindonesia.ac.id ${ }^{1}$,suliaa47@gmail.com ${ }^{2}$ \\ DOI: http://dx.doi.org/10.31869/rtj.v2i2.1300
}

\begin{abstract}
Abstrak: Zakat merupakan ibadah mahdah yang berkaitan dengan harta benda. Zakat juga merupakan salah satu perwujudan kepedulian sosial dalam hidup bermasyarakat. Badan Amil Zakat Nasional kota Padang adalah suatu instansi yang mengelola, mengumpulkan serta menyalurkan zakat kepada yang berhak menerimanya. Namun proses penerimaan calon penerima zakat masih bersifat manual, Pendaftar kesulitan mengantri serta menghabiskan waktu yang lama dan penggunaan kertas yang kurang efektif ketika melakukan pendaftaran manual. Agar proses pendaftaran penerimaan zakat lebih efektif dan efisien maka dibutuhkanlah suatu perubahan proses pendaftaran ke bentuk online terkomputerisasi. Sistem pendaftaran online yang dibangun menggunakan konsep Object Oriented Programming (OOP) dan bahasa pemrograman PHP, penelitian ini membantu mempermudah pihak Baznas maupun pihak Pendaftar untuk melakukan pendaftaran zakat secara online.
\end{abstract}

\section{Kata Kunci: Sistem Informasi, Pendaftaran Online, Zakat}

Abstract: Zakat is mahdah worship related to property. Zakat is also one of the manifestations of social concern in community life. The Padang National Amil Zakat Agency is an agency that manages, collects and distributes zakat to those entitled to receive it. But the process of receiving prospective zakat recipients is still manual, Registrants have difficulty queuing and spend a long time and the use of paper is less effective when conducting manual registration. In order for the registration process of zakat receipts to be more effective and efficient, it requires a change in the registration process to a computerized online form. Online registration system that was built using the concept of Object Oriented Programming (OOP) and the PHP programming language, this study helped facilitate the Baznas and the Registrants to register zakat online.

Keywords: Information System, Online Registration, Zakat

\section{PENDAHULUAN}

Teknologi informasi adalah merupakan hal yang sedang berkembang dengan baik pada saat ini, perkembangannya pun sangat membantu diberbagai aspek kehidupan, salah satu bentuk teknologi adalah media internet yang merupakan suatu hal yang dipergunakan oleh masyarakat untuk mengakses informasi, menginput data dan melakukan pendaftaran online melalui sebuah website. Badan Amil Zakat Nasional (Baznas) kota Padang adalah suatu instansi yang mengelola, mengumpulkan serta menyalurkan zakat kepada yang membutuhkan. Proses penerimaan calon penerima zakat yang dilakukan pun masih berupa metode manual, penerima zakat datang langsung ke Baznas kota Padang dan mendapatkan nomor antrian untuk mengantri mendaftar menjadi calon penerima zakat dengan membawa surat permohonan dan beberapa dokumen atau syarat-syarat yang diperlukan.

Hal ini pun memerlukan waktu yang lama, tenaga dan biaya, baik dari pihak Baznas maupun dari pihak penerima zakat serta banyaknya penggunaan kertas. Para calon penerima zakat masih kesulitan untuk mengantri sekedar mendaftar sebagai penerima zakat. Dengan adanya proses pendaftaran penerima zakat yang masih manual maka dibutuhkanlah suatu perubahan proses ke bentuk terkomputerisasi agar proses pendaftaran lebih efektif dan efisien. Oleh karena itu sistem informasi pendaftaran online penerima zakat dibutuhkan untuk mempermudah orang yang kesulitan mendafar secara langsung ke Baznas dan mempercepat dalam hal pendaftaran bagi calon penerima akat dan pengolahan data yang akan ditangani oleh pihak badan amil zakat kota Padang. 
Dari uraian permasalahan di atas, maka dibutuhkanlah suatu sistem online yang bisa membantu mempermudah pendaftaran calon penerima zakat, mengurangi tenaga biaya serta tidak menghabiskan waktu dari kedua belah pihak. Sistem yang dibangun untuk membantu mengatasi masalah pada sistem manual yang sedang berjalan.

\section{METODOLOGI PENELITIAN}

Untuk memperoleh data yang akurat dalam penelitian ini, maka penulis menggunakan metode pengumpulan data sebagai berikut:

1. Penelitian lapangan (field research)

Pengumpulan data atau informasi langsung dilakukan pada objek penelitian yaitu dengan 3 cara sebagai berikut:

\section{a. Observasi (Observation)}

Dengan mendatangi kantor Baznas kota Padang khusunya pada bagian administrasi untuk menanyakan dan melihat proses system pendaftaran calon para penerima zakat yang sedang berjalan.

b. Wawancara (Interview)

Menanyakan secara langsung kepada bagian administrasi dan penyalur zakat Baznas kota Padang untuk melakukan wawancara.

c. Kuisioner

Memberikan daftar pertanyaan kepada narasumber atau pihak Baznas terkait data penelitian pendaftaran online ini.

2. Penelitian Kepustakaan (Library research) Yaitu metode pengumpulan data dengan mempelajari buku-buku yang berhubungan dengan pendaftaran online sebagai landasan teori yang dapat memperkuat penelitian ini, juga pengumpulan data yang bersumber dari kliping, artikel, jurnal, literature serta internet yang berkaitan dengan penelitian ini.

3. Penelitian Laboratorium (Laboratorium research)

Metode yang dilakukan dilabor dengan data yang telah dikumpulkan kemudian diolah dengan menggunakan hardware dan software computer. Dalam penelitian ini digunakan sebuah Personal Computer (PC) yang mana hardware dan software yang terpasang pada perangkat computer, spesifikasi alat (device) yang digunakan dalam penelitian.

4. Metode Pengembangan Sistem

Sistem yang dibangun akan menggunakan konsep Object Oriented Programming (OOP) untuk memudahkan pengembangan lebih lanjut, karena menggunakan konsep OOP maka perancangan pada pembuatan sistem ini menggunakan UML untuk mempermudah pengembang dalam membangun sistem pendaftaran online ini. UML adalah bahasa pemodelan untuk sistem atau perangkat lunak yang berparadigma berorientasi objek. Pemodelan sesungguhnya digunakan untuk penyederhanaan permasalahan-permasalahan yang kompleks sedemikian rupa sehingga lebih mudah dipelajari dan dipahami.

\section{HASIL DAN PEMBAHASAN}

1. Sistem Informasi

Sistem dapat didefinisikan sebagai kumpulan dari komponen yang saling berhubungan satu dengan yang lainnya membentuk satu kesatuan untuk mencapai suatu tujuan tertentu [1].

Sistem informasi adalah suatu sistem di dalam suatu organisasi yang mempertemukan kebutuhan pengolahan, transaksi harian yang mendukung fungsi operasi organisasi yang bersifat manajerial dengan kegiatan strategi dari suatu organisasi untuk dapat menyediakan laporan-laporan yang diperlukan [2].

Berdasarkan pendapat di atas, dapat disimpulkan bahwa sistem informasi merupakan sekumpulan software, hardware, brainware, prosedur dan aturan-aturan yang diorganisasikan secara integral untuk mengolah data menjadi informasi yang bermanfaat guna memecahkan masalah untuk mendukung pengambilan keputusan dan kendali dalam organisasi.

2. Pengertian Sistem Informasi Pendaftaran

Menurut kamus besar bahasa Indonesia pendaftaran adalah proses, cara, perbuatan mendaftar (mendaftarkan) pencatatan nama, alamat dan sebagainya dalam daftar. Sedangkan pengertian sistem informasi merupakan entitas (kesatuan) formal yang terdiri dari berbagai sumber daya fisik \& logika. Dari organisasi ke organisasi, sumber daya ini disusun dengan beberapa cara karena organisasi \& sistem informasinya merupakan sumber-daya dinamis [3].

\section{Pengertian Sistem Online}

Pengertian sistem online adalah sistem yang menerima langsung input pada area dimana input tersebut direkam, dan menghasilkan output berupa hasil komputasi pada area dimana mereka dibutuhkan. Dari pengertian 
tersebut bisa disimpulkan bahwa sistem online merupakan suatu sistem yang terdiri dari berbagai perangkat yang saling terhubung satu dengan lainnya, bisa diakses dimana saja dan kapan saja tanpa terikat waktu dan tempat asalkan terhubung atau terkoneksi dengan jaringan internet [4].

4. Zakat

Ditinjau dari segi bahasa, kata zakat merupakan kata dasar dari "zakka" yang berarti suci, berkah, tumbuh dan terpuji. Sedangkan dari segi istilah fiqh, zakat berarti sejumlah harta tertentu yang diwajibkan Allah yang diserahkan kepada orang yang berhak menerimanya. Zakat juga merupakan upaya mensucikan dan membersihkan diri dari kotoran sifat kikir dan dosa, serta menyuburkan pahala melalui pengeluaran sedikit dari nilai harta pribadi untuk orang-orang yang memerlukan. Oleh karena itu, ketika seseorang sudah mengeluarkan zakat maka ia telah suci (bersih) dirinya dari penyakit kikir dan tamak [5].

Zakat memastikan transfer harta kepada kelompok atau golongan yang kurang mampu (the have not), sehingga harta tersebut tidak beredar di kalangan mereka yang berlebih (the have) saja [6]. Di dalam al-Qur'an terdapat dua puluh tujuh ayat yang mensejajarkan kewajiban shalat dengan zakat dalam berbagai bentuk kata [7].

Orang-orang yang berhak menerima zakat (mustahik) adalah orang atau entitas yang berhak menerima zakat, sebagaimana terdapat dalam surah at-Taubah ayat 60 : "Sesungguhnya zakat-zakat itu hanyalah untuk orang-orang fakir, orang-orang miskin, pengurus-pengurus zakat, para mualaf, orangorang yang berutang untuk jalan Allah dan orang-orang yang sedang dalam perjalanan, sebagai suatu ketetapan yang diwajibkan Allah dan Allah maha mengetahui lagi maha bijaksana" (Qs; at-Taubah (60) [8].

Muzakki adalah individu muslim yang secara syariah wajib untuk membayar zakat. Amil adalah pihak pemerintah untuk menangani urusan pemungutan zakat dari sumbernya dan menyalurkan kepada yang membutuhkan.

5. Mekanisme Pendaftaran Penerima Zakat Mekanisme pendaftaran penerima zakat pada Baznas kota Padang saat ini masih berjalan manual, mustahik mendatangi kantor Baznas dengan membawa sejumlah dokumen atau surat-surat persyaratan sesuai jenis zakat yang ingin diajukan oleh Mustahik. Kemudian mengambil nomor antrian serta menunggu untuk dilayani satu persatu oleh bagian administrasi, sesuai nomor antrian. Mereka akan dilayani oleh bagian administrasi untuk menyerahkan sejumlah dokumen persyaratan untuk mengajukan bantuan zakat. Oleh karena itu Mustahik akan mengisi surat pernyataan survey yang diberikan oleh bagain pelayanan atau administrasi. Surat pernyataan survey bertujuan untuk melihat kondisi real dari lingkungan Mustahik dan juga untuk mengurangi agar bantuan zakat tidak diberikan kepada orang yang kurang tepat. Setelah itu dokumen mereka akan diproses, surat permohonan bantuan diagendakan apabila sesuai dengan ketentuan program. Adapun maksudnya disini surat permohonan atau berkas Mustahik akan dikabulkan jika semua syarat sesuai dan telah terpenuhi dengan ketentuan yang berada disetiap jenis zakat. Semua surat masuk tidak bisa diambil lagi dan menjadi arsip Baznas kota Padang.

6. Syarat Penerimaan Zakat

Pendistribusian dana zakat oleh Baznas Kota Padang dari tahun ketahun diupayakan sebaik mungkin dengan melahirkan ide-ide baru. Dalam rangka memudahkan proses pendistribusian dan semakin terkontrolnya setiap pendistribusian dana zakat tersebut dipandang perlu menyusun mekanisme teknis pendistribusian melalui penguatan organisasi Baznas dan diketahui oleh semua pengurus. Program pendistribusian meliputi:

a) Bantuan pendidikan, sasarannya adalah memberikan bantuan kepada pelajar dan mahasiswa dalam bentuk anak putus beasiswa dan bantuan penyelesaian skripsi serta tesis.

b) Bantuan modal usaha, sasarannya adalah memberikan bantuan kepada fakir miskin dalam bentuk modal usaha, supaya dapat menjalankan usahanya dengan baik, seperti berdagang, nelayan dan bertani.

c) Bantuan kesehatan, sasarannya adalah memberikan bantuan kepada fakir miskin yang menghadapi masalah kesehatan dan memerlukan biaya untuk pengobatannya.

d) Bantuan perbaikan rumah dan lingkungan, sasarannya adalah memberikan bantuan 
kepada fakir miskin untuk memperbaiki rumah sehingga layak huni.

e) Bantuan tanggap darurat bencana dan recovery, sasarannya adalah memberikan bantuan kepada mereka yang ditimpa bencana alam yang mengakibatkan kehilangan atau kerusakan harta benda, sehingga menjadikan mereka fakir dan miskin. Misalnya kebakaran, banjir, gempa bumi dan bencana lainnya.

f) Bantuan keterampilan, sasarannya adalah memberikan bantuan kepada fakir miskin untuk mengikuti pendidikan atau pelatihan keterampilan supaya mereka memiliki kemampuan untuk berusaha dan bekerja dalam memenuhi kebutuhan hidupnya [9].

Dari tiap-tiap jenis zakat yang disediakan oleh Baznas kota Padang, masing-masingnya memiliki persyaratan yang berbeda-beda. Contohnya zakat untuk bantuan berobat, pihak Baznas akan mendatangi tempat atau rumah sakit tempat Mustahik dirawat untuk memastikan kondisi yang sebenarnya. Setelah itu melihat kondisi real atau kondisi nyata yang sebenarnya, maka pihak Baznas akan menyetujui atau menyalurkan zakat kepada Mustahik, hal ini dilakukan agar penyaluran zakat tidak diberikan kepada orang yang kurang berhak menerimanya.

7. Alat Bantu Pengembangan Sistem

Unified Modeling Language (UML) sering juga disebut dengan Unified Modeling Language merupakan pemodelan dengan penyederhanaan dari suatu permasalahan menggunakan gambaran-gambaran (diagram) yang lebih mudah untuk dipahami oleh berbagai pihak. Tujuan dari pemodelan adalah sebagai media visualisasi dan komunikasi antar berbagai pihak yang terlibat dalam pengembangan sistem atau perangkat lunak aplikasi [10].

\section{a) Use Case Diagram}

Use Case Diagram dapat sangat membantu bila kita sedang menyusun requirement sebuah system, mengkomunikasikan rancangan dengan klien, dan merancanag test case untuk semua feature yang ada pada sebuah sistem. Use case adalah rangkaian atau uraian sekelompok yang saling terkait dan membentuk sistem secara teratur yang dilakukan atau diawasi oleh sebuah actor. Use case digunakan untuk membentuk tingkah laku benda dalam sebuah model serta direalisasikan oleh sebuah kolaborasi [10].

\section{b) Class Diagram}

Diagram kelas atau class diagram menggambarkan struktur sistem dari segi pendefenisian kelas-kelas yang akan dibuat untuk membangun sistem. Kelas memiliki apa saja yang disebut atribut dan metode atau operasi [11].

c) Sequence Diagram

Sequence Diagram yaitu salah satu jenis diagram yang ada pada UML yang menggunakan interaksi objek dan waktu. Sequence Diagram mengambarkan interaksi antara sejumlah objek dalam urutan waktu. Dimana kegunaannya untuk menunjukkan rangkaian pesan yang dikirim antara objek juga interaksi antar objek yang terjadi pada titik tertentu dalam eksekusi sistem. Pada diagram sequence setiap hanya memiliki garis yang digambarkan garis putus-putus ke bawah [10].

d). Activity Diagram

Membuat activity diagram pada awal pemodelan proses cukup menguntungkan untuk membantu memahami keseluruhan proses. Activity Diagram memodelkan workflow bisnis dan urutun aktivitas dalam sebuah proses". Diagram ini sangat mirip dengan flow chart karena memodelkan workflow dari satu aktivitas ke aivitas lainya atau dari aktivitas ke status [10].

e) Bahasa Pemrograman

PHP merupakan singkatan dari "Hypertext Preprocessor" yang digunakan untuk membuat tampilan web mejadi lebih dinamis yang terhubung dengan database. PHP adalah bahasa script server side dalam pengembangan web yang disisipkan pada dokumen HTML yang didesain khusus untuk aplikasi web [12].

f) Database

MySQL merupakan software RDBMS (Relasional Database Management System) atau server database yang dapat mengelola database dengan sangat cepat, dapat menampung data dengan jumlah yang besar, dapat diakses dengan banyak user (multi user), dan dapat melakukan suatu proses secara sinkron atau bersamaan (multi-threaded). MySql merupakan RDBMS yang mendukung database yang terdiri dari sekumpulan relasi atau tabel [12].

g) Analis dan Desain

Untuk mengatasi masalah yang ada pada saat ini, diperoleh perancangan untuk membangun suatu sistem yang baru agar kebutuhan pada 
sistem ini terpenuhi. Analisis kebutuhan sistem secara garis besar membahas tentang kebutuhan sistem aplikasi. Untuk mengubah sistem yang lama menjadi terkomputerisasi, maka perlu dilakukan pengembangan sistem informasi, dimana pada sistem yang lama dilakukan pengolahan data dan pendaftaran secara manual yang belum efektif dan efisien. Pada sistem yang baru hampir sama dengan alur manual. Hanya saja berbeda dari segi pendaftaran dan pengolahan data menjadi pendaftaran online dan penyimpanan data ke database dan menghasilkan laporan dengan menggunakan bahasa pemrogram PHP dan database Mysql. Berikut ini adalah diagram use case diusulkan yang terlihat pada Gambar 1.

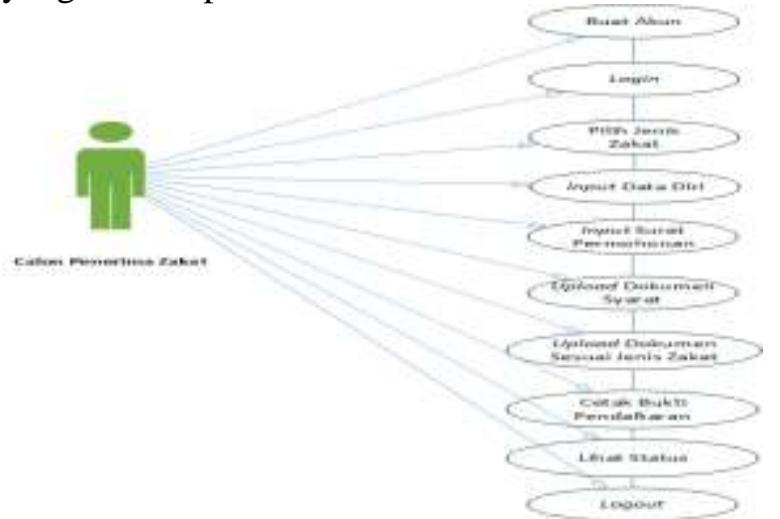

Gambar. 1 Use Case Diagram Calon Penerima Zakat

Alur use case sistem baru yang diusulkan untuk bagian Administrasi terlihat pada Gambar 2.

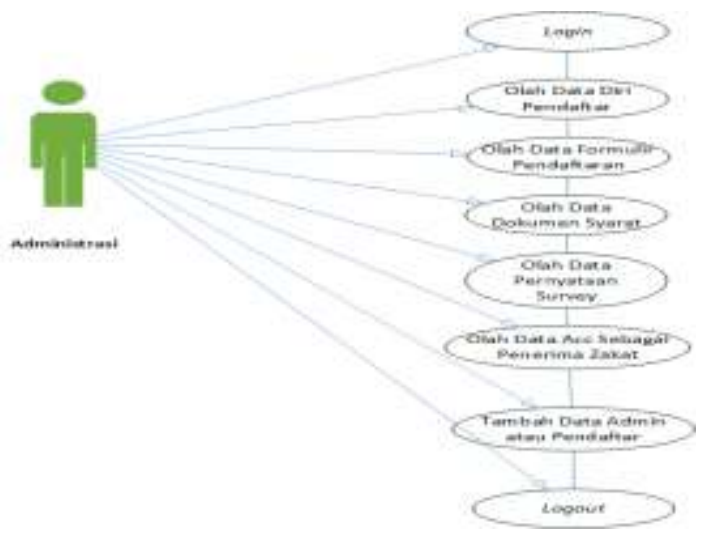

\section{Gambar 2. Diagram Use Case Bagian Administrasi}

Calon penerima zakat mendatangi Baznas kota Padang untuk mendaftar menjadi penerima zakat lalu mengambil nomor antrian dan mengantri untuk dilayani oleh bagian administrasi. Sistem yang ada pada bagian penerima zakat ini belum memiliki sistem yang terkomputerisasi sehingga membutuhkan waktu yang lama bagi penerima zakat untuk dilayani satu persatu sekedar untuk mendaftar. Selama ini pendaftaran yang dilakukan belum dilaksanakan secara online, masih menggunakan nomor antrian dan mengantri di Baznas dengan membawa sejumlah dokumen persyaratan sesuai dengan jenis zakat yang diinginkan.

Tentu hal ini menghabiskan waktu yang lama, biaya yang dikeluarkan untuk mendatangi kantor Baznas serta tenaga yang digunakan untuk mengantri sekedar untuk mendaftar. Agar mempermudah kedua belah pihak baik pihak pendaftar (Mustahik) maupun pihak Baznas maka dibuatkan suatu aplikasi yang dapat digunakan secara online dalam hal pendaftaran calon penerima zakat. Aplikasi yang diusulkan di sini adalah sistem informasi pendaftaran online bagi penerima zakat, dimana aplikasi ini membantu untuk mempermudah dan menghemat waktu tenaga serta biaya dari kedua belah pihak yang terkoneksi secara online dan bisa diakses kapan saja dan dimana saja oleh calon penerima zakat. Hal ini juga dapat membantu bagian Administrasi penerima zakat untuk mengolah data pendaftar secara online dan tersimpan pada database.

Setelah dilakukan analisis pada sistem yang sedang berjalan dari beberapa masalah dan kendala-kendala yang terjadi pada sistem tersebut. Oleh karena itu dapat disimpulkan bahwa perlu adanya suatu sistem online yang dapat membantu dalam proses pendaftaran yang bisa diakses dimana saja dan kapan saja dan semua data pendaftaran tersimpan dalam database.

Adapun jabaran dari hasil analisis sistem tersebut adalah sebagai berikut :

a. Belum tersedia sistem informasi pendaftaran online pada bagian pendaftaran penerima zakat.

b. Pendaftar kesulitan mengantri untuk mendatangi Baznas untuk mendaftar menjadi penerima zakat.

Perancangan sistem terinci bertujuan untuk memberi gambaran dan rancang bangun yang jelas kepada pemakai. Perancangan sistem terinci mencakup gambaran desain output 
desain input, desain database, dan desain file, serta desain relasi antar file.

Tahap implementasi merupakan tahap terakhir dalam pengembangan sistem, yaitu meletakkan sistem supaya siap dioperasikan. Sistem Informasi yang telah dibangun dan telah dilakukan pengetesan dari modul yang dirangkai. Sistem ini telah dianalisis dan didesain secara rinci dan didukung dengan memakai aplikasi pemrograman PHP, implementasinya berguna untuk memudahkan penerapan sistem yang telah disiapkan, agar pengentrian data sampai penyajian informasi sesuai dengan prosedur yang telah direncanakan.

Hasil implementasi sistem akan dijabarkan pada bab ini, bagaimana sebuah sistem manual yang telah bertransformasi menjadi sebuah sistem online yang terkomputerisasi. Dari beberapa kegiatan implementasi sistem dimulai dari halaman utama untuk login Admin dan halaman utama untuk login Pendaftar.

a. Halaman Login Admin

Admin dapat mengakses halaman admin dengan login terlebih dahulu pada form login admin. Halaman login admin bisa dilihat pada Gambar 3.

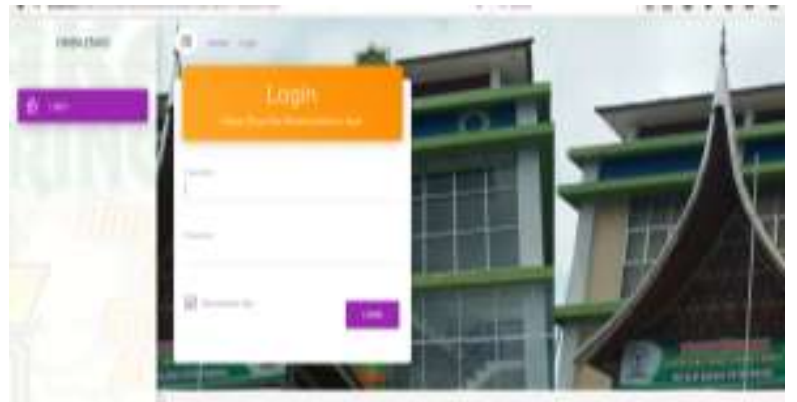

Gambar 3. Tampilan Halaman Login Admin

b. Halaman Login Calon Penerima Zakat

Halaman login calon penerima zakat terlihat pada Gambar 4.

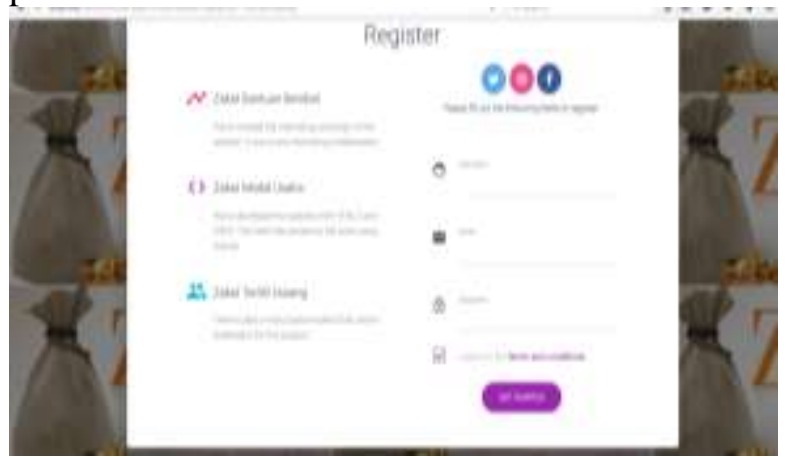

Gambar 4. Tampilan Form Login Calon Penerima Zakat

ISSN 2599-2081

Fakultas Teknik
Program yang dirancang merupakan suatu program yang saling berkaitan antara satu menu dengan menu lainnya, maka user harus melakukan tahap demi tahap atau langkahlangkah yang sudah dirancang. Tahap pertama yang harus dilakukan oleh user adalah menginput data, berikut ini akan dijelaskan bentuk dari input data tersebut secara lebih rinci.

1. Form Entry Formulir Pendaftaran

Form data formulir pendaftaran berfungi untuk mengentrikan data diri Pendaftar dan mengupload sejumlah dokumen syarat sesuai jenis zakat yang diinginkan Pendaftar. Form input data formulir pendaftaran tersedia pada menu Admin dan menu Pendaftar seperti pada Gambar 5.

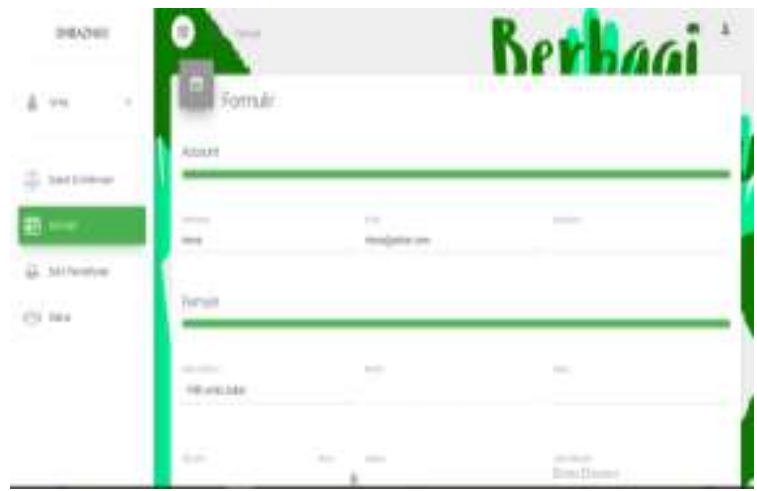

Gambar 5. Tampilan Form Entry Formulir Pendaftaran

2. Form Entry Jenis Zakat

Pada form input jenis zakat terdapat sub menu untuk menambah, mengedit atau menghapus data jenis zakat yang terlihat pada Gambar 6 .

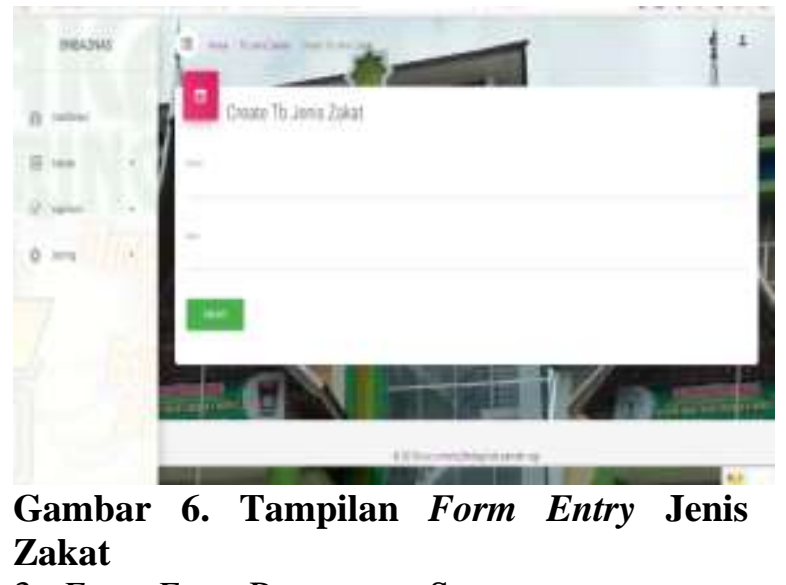

\section{Form Entry Pernyataan Survey}

Pada form pernyataan survey admin akan menyeleksi calon penerima zakat dengan

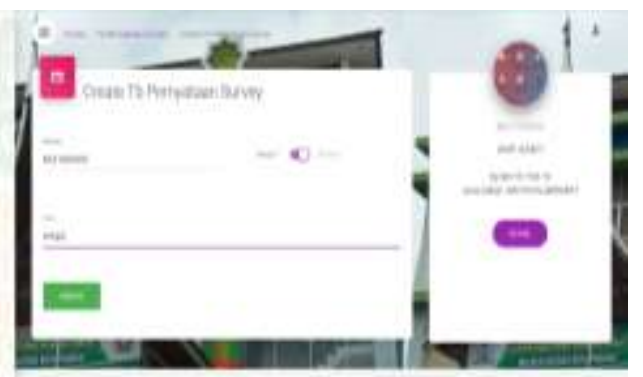


menyetujui pernyataan survey yang terlihat pada Gambar 7.

Gambar 7. Tampilan Form Entry Pernyataan Survey

4. Form Entry Tambah Admin

Form input data tambah admin berguna untuk menambah admin atau user sebagai pengguna sistem pada bagian backend. Sistem menggunakan super admin agar pihak Baznas bisa menambahkan pegawainya sebagai user. Terlihat pada Gambar 8.

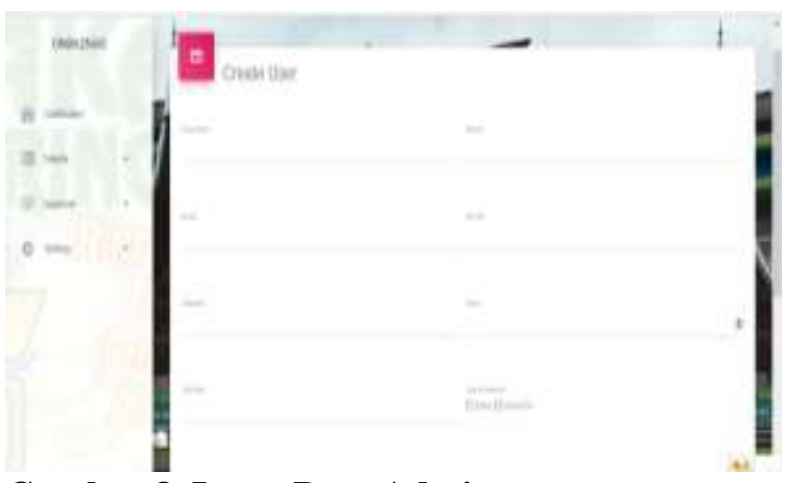

Gambar 8. Input Data Admin

Dengan mengklik button Library_Add maka admin bisa menambahkan admin baru atau pengguna baru untuk memberikan hak akses pada sistem ini.

c. Menu Input

1. Input Berkas Syarat Formulir Pendaftaran (FP) Jenis Zakat Bantuan Berobat.

Pada formulir pendaftaran pendaftar akan memilih jenis zakat yang diinginkan, selain berkas utama pendaftar akan diminta menginputkan sejumlah berkas dokumen syarat berupa gambar yang diupload ke sistem seperti yang terlihat pada Gambar 9.

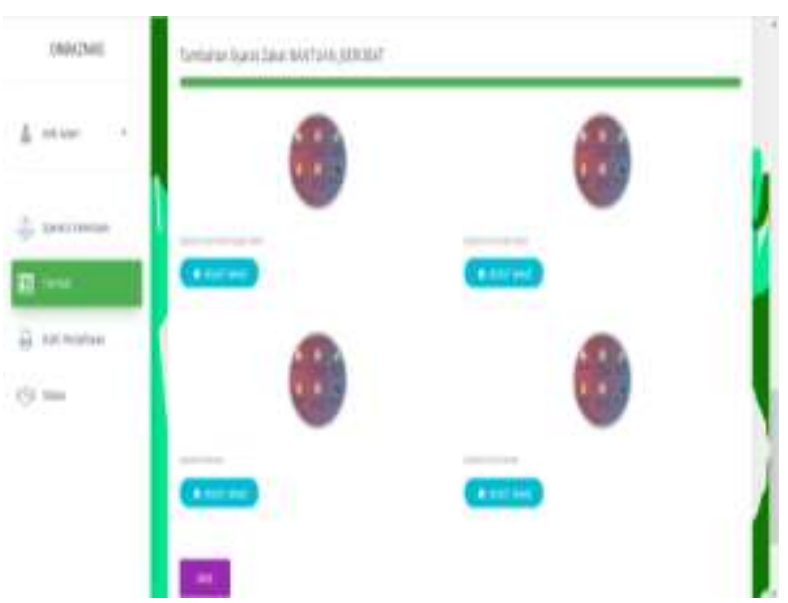

Gambar 9. Input Data Berkas Syarat FP Jenis Zakat Bantuan Berobat

2. Input Data Berkas Syarat Formulir Pendaftaran (FP) Jenis Zakat Modal Usaha.

Form upload berkas syarat zakat bantuan usaha terlihat pada Gambar 10.

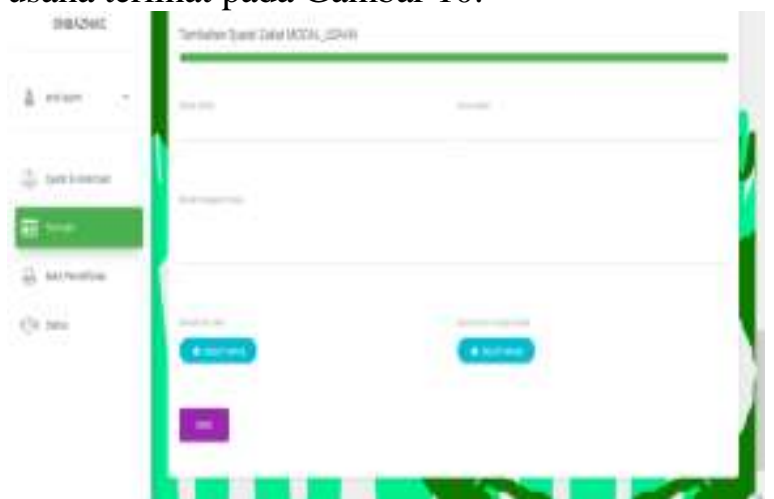

Gambar 10. Input Data Berkas Syarat FP Jenis Zakat Modal Usaha

3. Input Data Berkas Syarat Formulir Pendaftaran (FP) Jenis Zakat Terlilit Hutang

Form upload berkas syarat jenis zakat terlilit hutang terlihat pada Gambar 11.

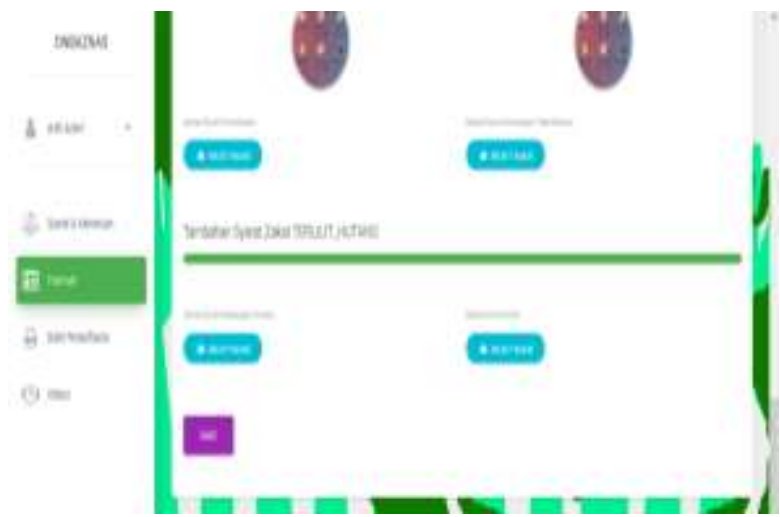

Gambar 11. Input Berkas Syarat FP Jenis Zakat Terlilit Hutang

\section{d. Output}

1. Cetak Bukti Pendaftaran

Form cetak bukti pendaftaran merupakan output untuk pendaftar. Laporan mengetahui apakah pendaftar sudah terdaftar secara lengkap atau belum. Terlihat pada Gambar 12 . 


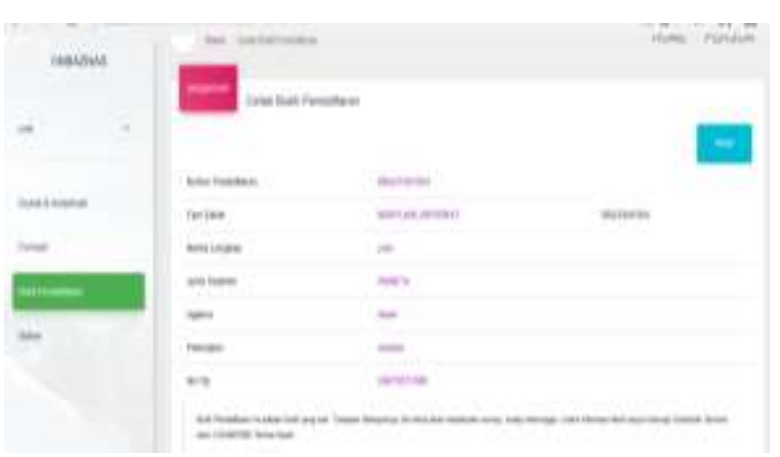

Gambar 12. Cetak Formulir Pendaftaran

2. Status Pendaftaran

Output status pendaftar merupakan keluaran yang bisa dilihat oleh user ketika mereka login sistem untuk melihat status pendaftaran seperti pada Gambar 13.

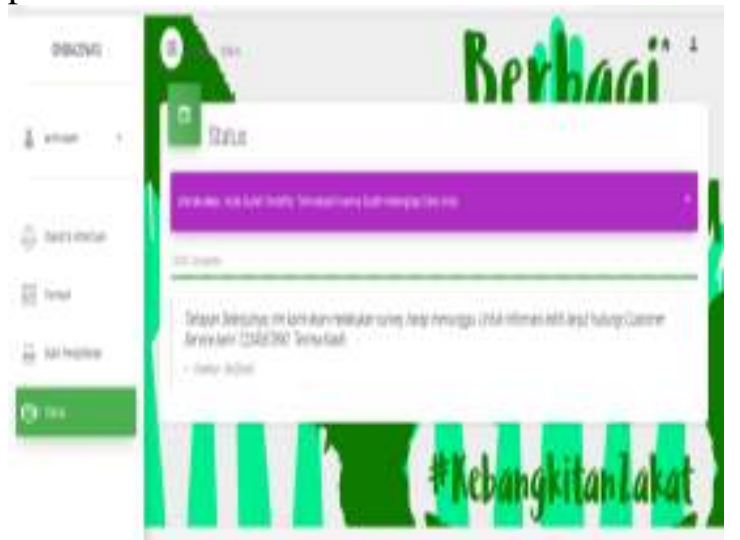

Gambar 13. Tampilan Status Pendaftaran

3. Laporan Formulir Pendaftaran

Output formulir pendaftaran merupakan laporan dari data pendaftar yang telah mendaftar ke sistem. Terlihat pada Gambar 14.

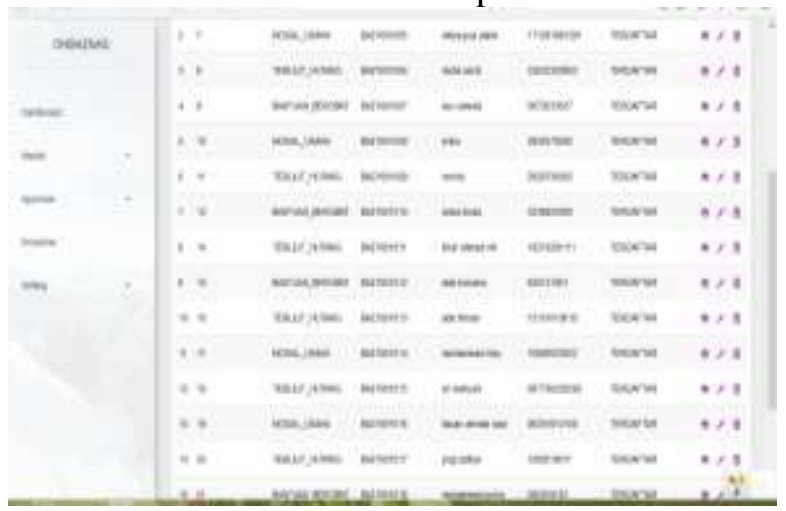

Gambar 14. Tampilan Laporan Formulir Pendafataran

4. Laporan Pernyataan Survey

Sedangkan output formulir pendaftaran yang telah disetujui untuk survey bisa dilihat pada Gambar 15.

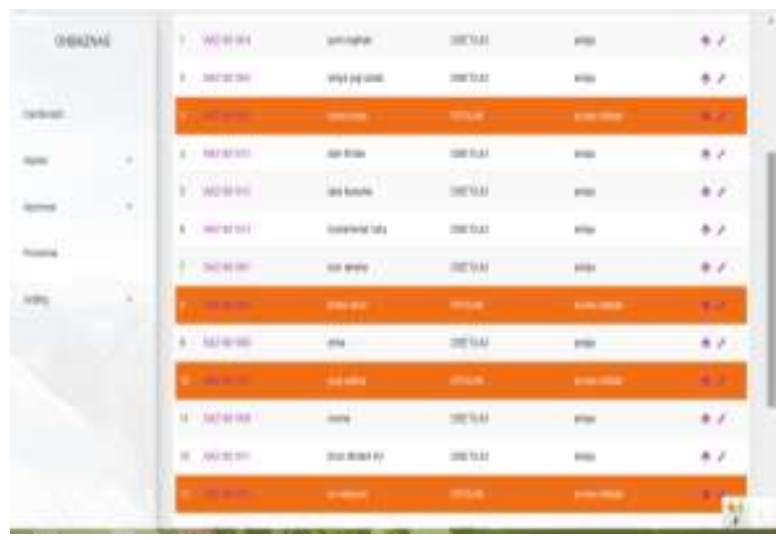

Gambar 15. Tampilan Laporan Pernyataan Survey

5. Laporan Data Acc Sebagai Penerima

Merupakan laporan data dari pendaftar yang di acc atau diterima sebagai penerima

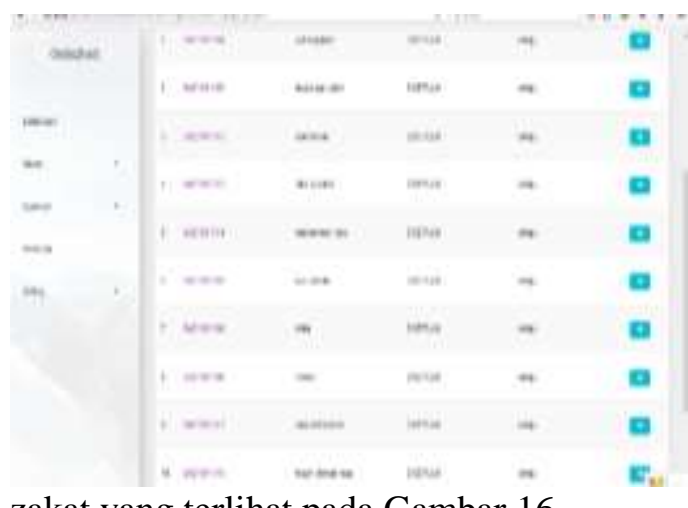

zakat yang terlihat pada Gambar 16.

\section{Gambar 16. Laporan Acc Sebagai Penerima PENUTUP}

Berdasarkan uraian yang dikemukakan pada bab-bab sebelumnya dapat disimpulkan dari penelitian yang dilakukan diharapkan bermanfaat bagi pembaca pada umumnya dan bagi pihak yang bersangkutan, adapun kesimpulannya yang dapat dikemukakan antara lain :

1. Dengan adanya aplikasi pendaftaran online ini pendaftaran penerimaan zakat pada Baznas kota Padang sudah tidak menggunakan metode manual dalam menerima pendaftaran calon penerima zakat.

2. Baznas kota Padang dalam mengolah data pendaftaran calon penerima zakat dengan aplikasi ini dapat lebih efektif dan efisien.

3. Menggunakan sistem online yang terkomputerisasi berkurangnya penggunaan kertas, berkurangnya biaya, waktu, dan 
tenaga dari pihak Baznas maupun dari pihak penerima zakat ketika melakukan pendaftaran secara manual.

4. Sistem pendaftaran online ini dapat membantu orang yang kesulitan untuk mengantri sekedar untuk mendaftar menjadi penerima zakat pada Baznas kota Padang.

\section{UCAPAN TERIMAKASIH}

Ucapan terima kasih kepada Yayasan Amal Bakti Mukmin yang telah memberikan dana dalam penulisan penelitian ini hingga selesai. Pada akhir kata kami mengucapkan terima kasih kepada Ketua STMIK Indonesia Padang dan Ketua LPPM STMIK Indonesia Padang, yang telah mendorong dan terus memberikan semangat serta motivasi agar terus maju dan berinovasi dalam melakukan penelitian.

\section{DAFTAR PUSTAKA}

[1] L. D. Putri, 2014, Perancangan Sistem Informasi Penerimaan Siswa Baru Pada Sekolah Menengah Kejuruan Negeri 3 Pacitan, IJNS-Indones. J. Netw. Secur, Vol.3, No.4, pp. 2-5, 2014.

[2] T. Sutabri, 2012, Analisis Sistem Informasi. Yogyakarta: Andi Offset

[3] E. Prahasta, 2014, Sistem Informasi Geografis: Konsep-Konsep Dasar (Perspektif Geodesi dan Geomatika), Bandung: Informatika Bandung

[4] I. Pohan, 2014, Pengantar Perancangan Sistem, Jakarta: Erlangga

[5] H. Widyani, 2014, Analisis Penanggulangan Kemiskinan Melalui Implementasi Program Dana Bergulir Badan Amil Zakat Kota Bandung, Afkaruna, Vol.10, No.0037, pp. 180-201, DOI.

[6] D. Suprianto, 2015, Pengaruh Zakat Dalam Meningkatkan Kesejahteraan Masyarakat Miskin Di Kecamatan Sumbawa, J. Ekon. dan Bisnis, Vol.3, No.8, pp. 1-24.

[7] M. Siradj, 2014, Jalan Panjang Legislasi Syariat Zakat di Indonesia: Studi terhadap Undang-Undang Nomor 23 Tahun 2011 Tentang Pengelolaan Zakat, J. Bimas Islam, Vol.7, No.3, pp. 409448.

[8] Departemen Agama RI, 1992, al-Qur'an dan Terjemahnya, Semarang: PT: Tanjung Mas Inti, Departemen Agama
RI, al-Qur'an dan Terjemahnya, Semarang: PT: Tanjung Mas Inti.

[9] Arsip Baznas Kota Padang, 2014, Dokumen Arsip Badan Amil Zakat Nasional Kota Padang. Padang: Badan Amil Zakat Nasional.

[10] D. Urva, 2015, Pemodelan UML EMarketing Minyak Goreng, J. Teknol. dan Sist. Inf, Vol.1, No.2, pp. 92-101.

[11] M. S. Rosa A.S, 2015, Rekayasa Perangkat Lunak Tersruktur dan Berorientasi Objek. Bandung: Penerbit Informatika Bandung.

[12] F. Purwaningtias, 2015, Sistem Informasi Penerimaan Mahasiswa Baru Online Pada Universitas Palembang, J. Tek. Inform. Politek. Sekayu, Vol.3, No.2, pp. $46-52$.

$\begin{array}{lr}\text { Fakultas Teknik UMSB } & \text { ISSN 2599-2081 } \\ \text { EISSN 2599-2090 }\end{array}$

